\title{
Learner support system and academic performance of distance learning students in selected Kenyan public universities
}

Rebecca Mwikali Wambua ${ }^{a}$, Christopher Gakuu ${ }^{b}$, Harriet Kidombo ${ }^{b}$, and Speranza Ndege ${ }^{c}$

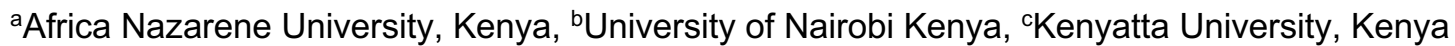

Vol 1 No 12019

ISSN: 2788-6298

DOI: https://doi.org/10.35293/tetfle.v1i1.69

\begin{abstract}
Distance learning is a mode of study globally accepted as a tool for enhancing access, equity and quality in education. The Kenyan Government has put in place mechanisms to promote open and distance learning practices in educational institutions. However, there is doubt in Kenya, regarding the quality of academic performance attained by distance learning students. The objective of this study was to determine the influence of learner support systems on the academic performance of distance learning students in selected Kenyan public universities. The study is based on Pragmatism due to its focus on objectivity and the use of scientific methods. Mixed-methods research methodology was adopted for the study. The sample consisted of 847 Bachelor of Education (Arts) distance learning students, 149 lecturers teaching distance learning students, and two (2) administrators in charge of distance learning programmes. The research instruments consisted of questionnaires, interview guides, document analysis and the instrument for measuring academic performance. The findings indicated that a learner support system statistically, significantly and positively influences academic performance of distance learning students, although at a low level (4.9\%). However, the findings revealed that guidance and counselling support, which is part of the learner support system, did not significantly influence the academic performance of distance learning students. The study recommends that particular focus should be on the provision of remotely accessible guidance and counselling services since most distance learning students cannot physically access the services which are on campuses.
\end{abstract}

Keywords: Distance learning, learner support system, academic performance

CONTACT Rebecca Mwikali Wambua @ rebeccawambua2015@gmail.com 


\section{Introduction}

Distance learning is a mode of study globally accepted as a tool for enhancing access, equity and quality in education (Muchiri, 2012; Wambugu 2012; Aluko, 2007). It is a mode of study in which the lecturer is separated by distance and time or both from the student. It involves extensive preparation of the media of delivery of content and the learner support system required to ensure distance learning students achieve the expected learning outcomes. Learners study as individuals with occasional face to face or virtual meetings with lecturers. The mode of study mainly attracts learners who are 25 years and above, who are working with family responsibilities, mainly with an intention of upgrading academic qualification to reach higher social economic status (Owusu-Boampong \& Holmberg, 2015; Muchiri, 2012). The rapid growth in technology, the flexibility offered by this mode of study, and the benefits which accrue to both individuals and governments as a result of investment in education have resulted in a rapid adoption of this mode of study (Hwang, Yang \& Kim, 2010).

\section{Literature Review}

Studies have been conducted since the early 1920s to compare the academic performance of students pursuing studies through various modes. Russell (2002) came up with No Significance Difference (NSD) phenomenon. He collated a bibliography of 355 pieces of research for the period 1927-1977 in the United States of America alone. The results of the researchers indicated that there is no significant difference in the academic performance of distance learning and conventional students. Recent studies reveal that distance learning students perform better than their conventional counterparts (Bailey, et.al. (2018). The academic performance of distance learning students directly impacts their career choice, social economic status and participation in community life (Benford \& Gess-Newsome, 2006). Different variables which contribute to the academic performance of students have been the subject of study by researchers, Bandura, 2001; Rugendo, 2014). According to Bandura's (2001) Socio-Cognitive theory, human behaviour is influenced by environmental factors and personal factors. In institutions of higher learning, factors within the institutions constitute environmental factors which affect the academic performance of distance learning students. 
One of the key institutional factors affecting the academic performance of distance learning students is the learner support system. The learner support system constitutes the holistic non-subject assistance provided to every student by an institution other than generic teaching materials. It includes services such as academic advisory, informational and ICT support, guidance and counselling services and, administrative support to students (SAIDE, 2003; Muchiri, 2012; Usun, 2004; Du Vivier, 2010). The learner support system not only determines the quality of the distance learning mode of study but also provides the competitive edge of an institution (Hwang, Yang \& Kim, 2010; Global Watch Missions, 2006). The learner support system should be an integral part of the teaching and learning process of distance learning programmes and it should focus on learners' needs. (Mays, 2017; Mills, 2003). An effective learner support system increases retention of students and reduces dropout rates (Tinto 2006-2007; Bojuwoye et.al., 2014; Simpson, 2015).

The Government of Kenya has put mechanisms in place to reduce the challenges of access, equity and quality faced at the institutions of higher learning. One of the plans is the establishment of the Open University of Kenya (Education Policy in Kenya, 2012; Sessional Paper No.1 of 2012 on A Policy Framework for Education, Training in Kenya; Sessional Paper No.1 of 2005 on A Policy Framework for Education, Training and Research (Open University of Kenya: Blueprint for the establishment of the Open University of Kenya, 2010). One of the main goals in education highlighted in the Kenya Vision 2030 is to reduce illiteracy, increase access, improve transition rates, achieve an $80 \%$ adult literacy rate and to increase the school enrolment rate to $95 \%$. It also aims at increasing the transition rates to technical institutions and universities from $3 \%$ to $8 \%$ by 2012. In the vision, public and private universities are encouraged to expand enrolment. An effective strategy of increasing access, transition and literacy is through encouraging distance learning mode of study, since more students can enrol with minimum strain on educational institutions.

Kenya has 22 chartered public universities and 14 chartered private universities. One of the critical roles of University Education in Kenya is to provide equity, access and quality 
in education (The Universities Act, 2012). In this study, Kenyatta University and the University of Nairobi have been purposively selected. These two universities have been charted for more than 10 years and they have offered distance learning programmes for more than 10 years. They have well-established directorates of the distance learning mode of study, with elaborate policies on learner support systems.

It is worth noting that most of the studies that have been carried out in the area of academic performance of distance learning students were mainly based in developed countries (Russell, 2002; Gallagher, et.al, 2005; Crowley et.al, 1999) and therefore the findings are not necessarily applicable to a developing country like Kenya. The majority of the studies in relation to the distance learning mode of study in Kenya have focused on issues other than academic performance namely; course delivery methods, readiness to adopt e-learning, factors influencing effective use of ICT in teaching and learning, effectiveness of a needs-based learner support system, and, the preparedness of students for ICT based learning (Njagi, 2012; Mulwa, 2012; Keiyoro, 2010; Muchiri 2012; Wambua et.al., 2012).

The limited research in the area of academic performance of distance learning students in Kenyan universities has resulted in scepticism regarding the quality of learning achieved through this mode of study (Wambugu, 2012). The enrolment of distance learning students in Kenya is quite low $(19,038)$ compared to overall university enrolment $(536,000)$, Nyerere, 2016). This study investigated the influence of the learner support system on academic performance of distance learning students. The purpose of this study was to establish the influence of learner support systems on the academic performance of distance learning students in selected Kenyan public universities. The objective of the study was to determine the influence of learner support systems on the academic performance of distance learning students in selected Kenyan public universities. The research question for this study was, 'How does the learner support system influence the academic performance of distance learning students in selected Kenyan public universities?" 
This study is based on an overlap of three schools of thought; constructivism, social cognitive and system's theories. According to constructivists such as John Dewey, Bruner, Piaget and Vygotsky, knowledge is constructed by learners based on their experiences. Therefore, in this study, the leaner support system has to be carefully designed to enable learners to construct knowledge out of the experience. Social cognitive theory is mainly associated with Albert Bandura who explains that both personal and environmental factors influence human behaviour. In this study, the academic support, administrative support and the guidance and counselling support put in place in the selected Kenyan public universities, constitute the environment which influences the academic performance of distance learning students. The system's theorists such as Luhman, Wiener, Churchman, Parsons and Bertalanffy, argue that institutions consist of elements which interact with each other to produce outputs. In this study, the distance learning students interact with the learner support system in order to achieve the learning outcomes.

\section{Research paradigm}

The research paradigm of this study is Pragmatism due to its emphasis on the need for objectivity and use of scientific methods in research (Onwuegbuzie \& Leech, 2006). The experiences of distance learners, lecturers teaching distance learning students and administrators in charge of distance learning programmes were critical and were expressed through carefully selected and constructed research instruments. A realistic ontology has been adopted in this study due to the assumption of the existence of cause and effect (Crotty, 2003). In this regard, therefore, the researcher adopted an ex post facto design which investigates the relationship and effects, between a dependent variable (learner support system) and an independent variable (academic performance of distance learning students). The epistemological assumptions in this study are from both positivist perspective (which assumes that knowledge is certain, objective, and unchanging) and from an interpretive perspective (which assumes that knowledge is uncertain, fluid, and dynamic) (Burke \& Onwuegbuziee, 2004). The use of both positivist and interpretive perspective influenced the use of mixed-method of research techniques. 


\section{Research Design and Methodology}

This study adopted ex post facto design (Orodho 2005). In this study, the independent variables were academic support, guidance and counselling support, and administrative support. The dependent variable was the cumulative mean score of Bachelor of Education (Arts) third-year distance learning students. The study was conducted at the University of Nairobi and Kenyatta University. The study further adopted a combination of qualitative and quantitative techniques (mixed-method research techniques) which supplement each other (Kothari, 2004). The techniques included interviews, document analysis, the use of questionnaires and the instrument of measuring academic performance.

To determine the sample size, Krecie and Morgan's (1970) statistical table for determining the sample sizes was used. The sample consisted of 847 Bachelor of Education (Arts) third-year distance learning students, 149 lecturers who teach Bachelor of Education (Arts) third-year distance learning students and two (2) administrators in charge of distance learning programmes from the selected Kenyan public universities. The sample size from the selected Kenyan public universities consisted of 475 Bachelor of Education (Arts) third-year distance learning students, 125 lecturers teaching Bachelor of Education (Arts) third-year distance learning students and two (2) administrators in charge of distance learning programmes.

A sequential sampling technique was used in selecting respondents. In the first phase, respondents from the University of Nairobi were selected, and in the second phase, the respondents from Kenyatta University were selected. In each phase, a stratified simple random sampling procedure was used (Orodho, 2005). The sub-samples from the two universities were joined to form a complete stratified sample. In this study, questionnaires, interview guides, document analysis and the document for measuring academic performance were used to collect data. Before collecting data, the researcher sought permission from the National Commission for Science, Technology and Innovation, the University of Nairobi, and Kenyatta University. The respondents were elucidated on the objectives of the study and they were requested to give their consent regarding 
R. WAMBUA ET AL.

participation in the study. Confidentiality was guaranteed. Data collected was reported without distortion.

\section{Results}

As shown in Table 1, the response rate was above $50 \%$ in all the categories of respondents which was considered significant for the study

\section{Table 1: Response rate}

\begin{tabular}{llcc}
\hline Item & Category of respondents & Frequency & Percentage \\
\hline Filled Questionnaires and & Lecturers & 73 & $58.4 \%$ \\
returned- Questionnaires & Lecturers & 52 & $41.6 \%$ \\
Not Returned & Total & 125 & 100 \\
& Bachelor of Education & 305 & $64.2 \%$ \\
& (Arts) third year Distance & & \\
Filled Questionnaires and & Learning Students & & \\
returned & & & \\
& & 170 & $35.8 \%$ \\
Questionnaires Not & Bachelor of Education & & \\
Returned & (Arts) third year Distance & & 100 \\
& Learning Students & 475 & $100 \%$ \\
\hline
\end{tabular}

Table 2 shows the descriptive statistics for the learner support system 
Table 2: Descriptive statistics for Learner Support System

\begin{tabular}{ccccc}
\hline $\begin{array}{c}\text { Learner support } \\
\text { system }\end{array}$ & Specific support & $\begin{array}{c}\text { Category of } \\
\text { Respondents }\end{array}$ & $\begin{array}{c}\text { Satisfaction } \\
\text { Percentage }\end{array}$ & $\begin{array}{c}\text { Satisfaction } \\
\text { Mean out of 5 }\end{array}$ \\
\hline Academic & Students & $72 \%$ & 3.6 \\
& support & Lecturers & $62 \%$ & 3.1 \\
Guidance and & Students & $62 \%$ & 3.1 \\
counselling & Lecturers & $54 \%$ & 2.7 \\
Administrative & Students & $72 \%$ & 3.6 \\
& Support & Lecturers & $72 \%$ & 3.6 \\
\hline Overall rating of Learner support & Students & $68.7 \%$ & 3.4 \\
\multicolumn{2}{c}{ system } & Lecturers & $62.7 \%$ & 3.1 \\
\hline Composite Mean for lecturers and students & $65 \%$ & 3.25 \\
\hline
\end{tabular}

The descriptive statistics for a learner support system shown in Table 2, indicates that the composite mean was 3.25 which was equivalent $65 \%$. This meant that regarding a learner support system, the selected Kenyan public universities needed to do much more to enhance the satisfaction of this support because $35 \%$ of lecturers and students were dissatisfied. This was supported by the fact that the dropout rate based on students enrolled by the first semester of the first year was $13.26 \%$.

\section{Quantitative statistics for a learner support system}

The objective of this study was to determine the influence of a learner support system on academic performance of distance learning students in selected Kenyan public universities. The hypothesis predicted that there is no relationship between a learner support system and academic performance. To test this hypothesis, a bivariate regression analysis for each of the sub-items under a learner support system was carried out to determine how each affected the academic performance of distance learning students in selected Kenyan public universities. 
Table 3: Bivariate regression results for Learner Support System and academic performance

\begin{tabular}{lccccc}
\hline Item & $\beta^{*}$ & $\mathrm{R}^{2}$ & $\mathrm{P}$ & $\mathrm{t}$-value & $\mathrm{F}$ \\
\hline Academic support & 0.546 & 0.020 & 0.013 & 2.490 & 6.21 \\
Guidance and counselling & 0.159 & 0.002 & 0.417 & 1.812 & 2.660 \\
Administrative support & 0.713 & 0.024 & 0.007 & 2.736 & 7.486 \\
Learner support & 0.421 & 0.049 & 0.043 & 2.560 & 17.16 \\
\hline
\end{tabular}

The outcome of the bivariate regression presented in Table 3 above shows that academic support explains $2.0 \%$ of the variance in the distance learning students' academic performance and it statistically and significantly influences academic performance $\left(R^{2}=\right.$ 0.020 , $p$-value $=0.013$ ). Specifically, a unit change in academic support is associated with 0.546 change in academic performance. The unstandardized beta coefficient, therefore, reveals that academic support substantially contributes to the academic performance of distance learning students in selected universities in Kenya $(\beta=0.546 ; p=0.013)$. The high calculated F-ratio of 6.21 which is greater than the critical $F$ ratio of 3.92 and $T$ values of 2.490 implies that the effect of academic support on academic performance is statistically significant at less than the 0.05 level of significance.

Guidance and counselling explain only $0.2 \%$ of the variance in academic performance and it is statistically not significant $\left(R^{2}=0.002, P=0.480\right)$ thus it is concluded that guidance and counselling support on its own does not influence academic performance of distance learning students from selected Kenyan public universities. The findings further revealed that a unit change in guidance and counselling explains a 0.159 change in academic performance. The un-standardised beta coefficient of $\beta=0.159$ confirms that guidance and counselling support on its own does not significantly affect the academic performance of learners in selected Kenyan public universities. The low calculated F-ratio of 2.66 and T values of 1.812 implies that the guidance and counselling support on its own does not statistically and significantly $(p=0.417)$ influence the academic performance of distance learners in selected Kenyan Public universities. 
Administrative support explains only $2.4 \%$ of the variance in the distance learning students' academic performance. This implies that although the model is significant $\left(R^{2}=0.020, P=0.000\right)$ only a very small proportion of academic performance is influenced by administrative support. The findings further revealed that a unit change in administrative support explains a 0.713 change in academic performance. The unstandardised beta coefficient of $\beta=0.713$ confirms that administrative support significantly influences the academic performance of learners in selected Kenyan public universities. The high calculated F-ratio of 7.486 and T values of 2.736 implies that the administrative support statistically and significantly influences the academic performance of distance learners in selected Kenyan Public universities $(p=0.024)$.

Finally, the entire learner support explains $4.9 \%$ of the variance in distance learners' academic performance $\left(R^{2}=0.049, P=0.043\right)$. This outcome indicates that there is a positive relation between learner support and academic performance of distance learning students from selected Kenyan public universities. A unit change in the composite learner support system explains a 0.421 change in academic performance. The un-standardised beta coefficient of $\beta=0.421$ reveals that learner support significantly affects the academic performance of learners in selected Kenyan public universities. The high calculated Fratio of 17.16 and $T$ values of 2.560 implies that the learner support system statistically and significantly influences the academic performance of distance learners in selected Kenyan Public universities $(p=0.049)$.

\section{Discussion}

The findings of this study do not agree with some of the results of a study by Bowa (2008) which revealed that most of the cognitive, affective, and systemic learner support services did not contribute significantly to the academic performance of learners because the services were either not adequately provided or because learners lacked access to the services. The current study revealed that academic support statistically and significantly influences academic performance $\left(R^{2}=0.020, p\right.$-value $\left.=0.013\right)$ although at a low level, $(2.0 \%)$, and, administrative support significantly influences academic performance $\left(R^{2}=0.024, P=0.007\right)$ although at a low level, $(2.4 \%)$. The entire learner support system explains $4.9 \%$ of the variance in distance learners' academic performance $\left(R^{2}=0.049\right.$, 
$\mathrm{P}=0.043$ ). This implies that the selected Kenyan public universities had improved slightly in their services in relation to academic support and administrative support. These findings are consistent with the study by Nyerere (2016) who discovered that universities in Kenya had put in place strategies to improve the learner support system of distance learning programmes

The findings in the study by Bowa (2008) further indicated that social services did not have a significant influence on academic performance because the services were low and ineffective. He established this through his study on the influence of the learner support services and learner characteristics on academic performance of Bachelor of Education (Arts) learners in the School of Continuing and Distance Education at the University of Nairobi. These findings are consistent with the current study which found that guidance and counselling do not significantly influence academic performance of distance learning students from selected Kenyan public universities.

The study revealed that guidance and counselling explain only $0.2 \%$ of the variance in academic performance and it is statistically insignificant $\left(R^{2}=0.002, P=0.417\right)$. These findings were consistent with the observation from the administrators who explained that although counselling services were available, the students, being distance learners, did not access the services adequately. This is despite clear information in the student information handbooks that pastoral and guidance services were offered through the chaplaincy. These findings imply that the provision of guidance and counselling services did not adequately serve the needs of distance learning students because they rarely came on campus. These findings support the recommendations by Muchiri (2012) who explained that there was a need for the guidance and counselling services to be reconceived to ensure access by distance learners, irrespective of their location. The findings are further supported by Kamau (2012) whose study revealed that there was a need to enhance the accessibility of the learner support system by distance learners. A study by Nyerere (2016) revealed that although universities in Kenya had implemented strategies to improve the learner support system, none of the 12 universities studied, indicated that they had social and career guidance services. Anyona (2009) found that 
there was a need to enhance the accessibility of guidance and counselling services because the learners were required to travel to the centres or campuses, to access these services. Regarding accessibility, Bailey, et.al. (2018) observed that one of the practices which lead to success in online learning is the provision of remotely accessible learner support structures. The need to use modern technology in supporting learner needs was also emphasized by different scholars (Chatpakkarattana \& Khlaisang, 2012; Baloyi, 2014).

\section{Conclusion}

The objective of this study was to determine the influence of a learner support system on academic performance of distance learning students in selected Kenyan public universities. The results indicated that the independent variable (learner support system) explains $4.9 \%$ of the academic performance $\left(R^{2}=0.049, F=17.16, p=0.043\right)$. It was therefore concluded that learner support, though only to a small percentage statistically, significantly, and positively determines the academic performance of distance learning students in selected Kenyan public universities. However, among the variables in the learner support system (academic support, guidance and counselling and administrative support), guidance and counselling support was the only variable which did not significantly influence academic performance of distance learning students. These findings imply that although the provision of academic support, guidance and counselling, and administrative support would result in higher levels of academic performance of distance learning students, more emphasis should be geared towards enhancing guidance and counselling support. Universities should ensure that policies are implemented so as to continuously improve the academic performance of distance learning students. Particular focus should be on the provision of remotely accessible guidance and counselling services since most distance learning students cannot physically access the services which are on campuses. 
R. WAMBUA ET AL.

\section{References}

Aluko F.R. 2007. A Comparative Study of Distance and Conventional Education Programmes Assessed in Terms of Access, Delivery and Output at the University of Pretoria. Pretoria, University of Pretoria.

Bailey A., Vaduganathan N., Henry T., Laverdiere R., \& Pugliese L. 2018. Making Digital Learning Work: Success strategies from six leading universities and community colleges. Boston: The Boston Consulting Group. [Online] Available from: https://edplus.asu.edu/sites/default/files/BCG-Making-Digital-Learning-Work-Apr2018\%20.pdf [Accessed on 28 April 2018].

Baloyi G.P. 2014. Learner Support in Open Distance and E-learning for Adult Students using Technologies. Journal of Communication, 5(2):127-133. [Online] Available from: https://pdfs.semanticscholar.org/1357/713a1dd36a33c9f4469e5952 27338428553e.pdf [Accessed on 30 April 2018].

Bandura A. 2001. Social cognitive theory: An agentic perspective. Annual Review of Psychology, pp.52, 1-26.

Benford S. \& Gess-Newsome, 2006. Factors Affecting Student Academic Success in Gateway Courses at Northern Arizona University. (online) available from: https://eric.ed.gov/?id=ED495693 accessed on 19 March, 2019.

Bojuwoye O., Moletsane M., Stofile S., Moolla N., \& Sylvester F. 2014. Learners' Experiences of Learning Support in Selected Western Cape Schools. South African Journal of Education. 34 (1). [Online] Available from: https://files.eric.ed.gov/fulltext/ EJ1136401.pdf [Accessed on 30 April 2018].

Bowa, 2008. The Influence of Learner Support Services on Academic Performance of Distance Learners: The Case of the University of Nairobi, External Degree Programme in Kenya. Unpublished doctoral thesis, University of Nairobi.

Burke J.R. \& Onwuegbuzie, A.J., 2004. Mixed Methods Research: A research paradigm whose time has come. Educational Researcher, 33(7), 14-26.

Chatpakkarattana T. \& Khlaisang J. 2012. The Learner Support System for Distance Education. Creative Education.Vol.3, 47-51 [Online] Available from: https://file.scirp. org/pdf/CE 2013011708304065.pdf [Accessed on 30 April 2018]. 
Carmel, A. \& Gold S. 2007.The Effects of Course Delivery Modality on Student Satisfaction and Retention and GPA in On-Site Vs. Distance Courses. Turkish Online Journal of Distance Education, April. 2007, ISSN 1302-6488, Vol.8, No.2, Article 11.

Crowley, J.R., Laurich, GA., Mobley, R.C., Arnette, AH., Shaikh, AH., \& Martin, SM.1999. Clinical laboratory technician to clinical laboratory scientists articulation and distance Clinical Laboratory Science,12(1),42-47.

Crotty, M. 2003. The Foundations of Social Research: Meaning and Perspectives in the Research Process. $3^{\text {rd }}$ edition, 10. London: SAGE Publications.

Gallagher, JE., Dobrosielski-Vergona, KA., Wingard, RG., and Williams, TM. 2005. Webbased vs. traditional classroom instruction in gerontology: A Pilot study. Journal of Dental Hygiene, 79(3), 1-10.

Gesinde, M. \& Akinwale, M.O., 2014. Trends and Future Directions in Open and Distance Learning Practice in Africa. Lagos: University of Lagos.

Global Watch Mission Report. 2006. Beyond E-learning: Practical insights from the USA, London: University of Abertay Dundee.

Government of the Republic of Kenya, 2012. A Policy Framework for Education. Aligning Education and Training to the Constitution of Kenya (2010) and Kenya Vision 2030 and Beyond. Nairobi: Government Press.

Government of the Republic of Kenya, 2005. A Policy Framework for Education, Training and Research. Nairobi: Government Press.

Government of the Republic of Kenya, 2007.Kenya Vision 2030. Nairobi: Government Press.

Government of the Republic of Kenya, 2012. The Universities Act, 2012. Nairobi: The National Council for Law Reporting.

Hwang, J D. Yang, H. \& Kim, H. 2010. E-learning in the Republic of Korea. Moscow: UNESCO.

Kamau, W.J. 2012. The effectiveness of learner support services to distance learners in a Primary Education Diploma: A case in Botswana. Unpublished doctoral thesis, University of Pretoria. 
R. WAMBUA ET AL.

Kcrecie \& Morgan, 1970, in Kasomo, D. 2006. Research Methods in Humanities and Education. Eldoret: Zapf Chancery.

Keiyoro, P.N. 2010. Factors influencing the effective use of ICT in teaching and learning Science Curriculum in Kenyan Secondary schools. Unpublished doctoral thesis, University of Nairobi.

Kothari, C.R. 2004. Research Methodology: Methods and Techniques. New Delhi: New Age International Publishers.

Mays, T.J. 2017. Utilizing Open Educational Resources in Support of Curriculum Transformation at Africa Nazarene University: A Participatory Action Research Approach. Unpublished doctoral thesis, University of Pretoria.

Mills, R. 2003. The Centrality of Learner Support in Open and Distance Learning: A paradigm shift in thinking. In A. Tait and R. Mills (Eds), Rethinking learner support in Distance Education: Change and continuity in an international context. London: Routledge Falmer.

Muchiri, P.W. 2012. Construction and Evaluation of the Effectiveness of a Needs-Based Learner Support System: The Case of the School of Continuing and Distance Education. Unpublished doctoral thesis, University of Nairobi.

Mulwa, A.S. 2012. The Influence of Institutional and Human Factors on the Readiness to Adopt E-learning: The case of secondary schools in Kitui District-Kenya. Unpublished doctoral thesis, University of Nairobi.

Nyerere, J. 2016. Open and Distance Learning in Kenya. Nairobi: Commonwealth of Learning.

Onwuegbuzie, A.J. \& Leech, N.L. 2006. Linking research questions to mixed methods data analysis procedures. The Qualitative Report. Vol.11, No.3, pp. 474-498.

Orodho, J. 2007.Techniques of Writing Research Proposals in Education and Social Sciences: Bureau of Educational Research, Kenyatta University. Nairobi: Masola Publications.

Owusu-Boampong \& Holmberg C. 2015. Distance Education in European higher education-The Potential. Oslo: International Council for Open and Distance Education. 
Rugendo, C.J. 2014. Influence of study habits and demographic variables on academic performance: The case of Bachelor of Education (Arts) students, University of Nairobi. Unpublished doctoral thesis, University of Nairobi.

Russell, T., 2002. 'The No Significant Difference Phenomenon" as reported in 355 research reports, summaries, and papers-a comprehensive research bibliography on technology for distance education. [Online] Available from: http://teleeducation.nb.ca/nosignificantdifference/ [accessed on 11 Oct 2018].

SAIDE, 2003.Minimum Targets for Distance Education in South Africa. Johannesburg: SAIDE.

Simpson, O. 2015. Student Support Services for Success in Open and Distance Learning. CEMCA EdTech Notes. [Online] Available from: https://www.researchgate.net/ publication/294428578_'Student_Support_Services_for_Success_in_Open_and_D istance_Learning [Accessed on 30 April 2018].

Tinto, V., 2006-2007. Research and Practice of Student Retention: What Next? Journal of College Student Retention, Vol. 8(1) 1-19. [Online] Available from: http://journals. sagepub.com/doi/pdf/10.2190/4YNU-4TMB-22DJ-AN4W [Accessed on 30 April 2018].

Usun, S., 2004. Learner Support Services in Distance Education Systems (A Case Study of Turkey) Turkish online journal of DE-TOJDE Oct 204ISSN 1302_6488 Vol.5 No.4 [Online] Available from: https://www.Turkish online journal of DE-TOJDE Oct 204ISSN 1302_6488 Vol.5 No.4 (accessed on 27 May, 2018)

Wambua, R.M. 2013. Head Teachers 'Preparedness for ICT Based Teaching in Kenya; A case of Primary School Head teachers in Eastern Province. Riara University First Annual International Conference on Education. Nairobi: Riara University

Wambua, R M, Mwaniki T., and Kibaara J. 2012. Kenyan University Students' Preparedness for ICT Based Learning. Nairobi, International Journal of Professional Practice.Vol.3 No.3pg.260-269.

Wambugu, L.N. 2012. A Comparative Analysis of Academic Performance of Bachelor of Education (Science) Distance and on-Campus learners at the University of Nairobi. An Unpublished doctoral thesis. Catholic University of East Africa. 